\title{
INVESTIGATING ABETTING JURISPRUDENCE AND ITS IMPLEMENTATION WITH IRAN THETICAL LAW BY FOCUSING ON THE NEW IPC (ISLAMIC PENAL CODE) ADOPTED IN 1392
}

\author{
Ehsan Dahmardeh \\ Islamic Azad University of Science and Research, Zahedan, Iran \\ Arman_k69@yahoo.com \\ Mohammad Amin Khammar \\ Shahrood Branch, Islamic Azad University, shahrood, Iran \\ Khammareng@yahoo.com
}

\begin{abstract}
One of the major issues in the IPC is the problem of accomplice in the crime, which is considered less. However, it can be seen that, this has an important place in jurisprudential rules. It can be seen that with reset refine in accordance with denial of contributions in crime rule, from the perspective of Islamic scholars, both Shia and Sunnite In terms of crime and sin and does not leave any doubt to investigators and lawyers and the general public, So that studies show, extending of the jurisprudential rule will spread In all dignities of people social life. But The Islamic Penal Code has the ambiguities related to accomplice in the crime, so, in the new IPC (Islamic Penal Code) adopted in 1392 was subject to review by the legislator. Accordingly, this study Investigated abetting jurisprudence and its implementation with Iran thetical law by focusing on the new IPC (Islamic Penal Code) adopted in 1392. The results showed these changes are due to the fact that in some cases, abrogating some of the provisions of previous legislation but the reforms have brought good results and has not in contradiction with jurisprudential rules.
\end{abstract}

Key words: The Islamic Penal Code, accomplice in the crime, contributions on of sin, jurisprudential rule

\section{INTRODUCTION}

One of the most important issues in criminal law in the area of "criminal liability" is issue of "complicity in the crime". Abetting was recognized by the criminal law of many countries and has its own rules, of course, the terms of the main discussion of the abetting. About its details because of substantiation conditions, or the penalty of complicity in the crime there are differences in the various criminal systems. In some legal systems, that are supporters of the "equality" idea according to that, the deputy punishment should be equivalent to the foreman punishment. In general, America and other common law countries can be considered among the proponents of this theory. From the perspective of the legal system an individual may be held responsible due to others commit acts, he acts as if it has been committed. In fact, collaboration or complicity in crime is emergent from the foreman of metaphysical duality, so, the act of foreman strangely, will be transferred to his partners. But there are another group of countries such as Germany and France which are on the contrary of the "equality" idea and believe that each individual penalty must be determined by the amount of his contribution to the commission of the crime. According to the aforementioned countries lawyers, each individual is responsible for his done actions. Thus, "the criminal responsibility of another action" or "attributive responsibility" has no place in criminal law. Also in criminal law of Iran the penalty of accomplice based on "subjective criteria" is milder than the foreman punishment unless, is "deputy as an independent crime" or "deputy of the ruling stewardship".[1] In fact, the legislator on this case placed a new criminal categories of "criminalization"

However, investigation and Penalty partnership in crime is also taken into consideration in the Islamic criminal law (policy).[2] The discussion in the Shia jurists and Usulis book has been asked entitled of 
"contributions in the crime" and "cooperative crimes and sins" and the discussion in the Sunnite jurists and Usulis book has been asked entitled of "the rule of preventing corruption action" that included certain provisions. For a detailed review partnership in crime in the Islamic criminal law which also said cooperative sins. In addition to present a definition and its committing methods should be studied the issue addressed in the verses and narratives and in this context the theory of jurists and Usulis should be noted. In this regard, Ahadi and Fakhlaie (1393) express with emphasis on verse 2 of holly surah entitled of the Maedeh Many jurists and commentators on the Qur'an statement "virtue, piety and do not cooperate in sin and aggression" have argued unlawfulness of sins contributions and the complicity in the crime but some have rejected this argument and with respect to the use of taboo word and there is also a transcendental context of "Cooperative" have criticized in the signifies holy verse. After reviewing evidence both groups by the analysis of philologists and interpreters and Islamic jurists opinions concluded that, the word "contributions" and "cooperation" in most cases, are synonymous also, just because of their subsequent expression and confrontation of the final two sentences of holy verse not being competent evidence to indicate prohibition on hate and restore cooperative action in the second sentence. Therefore, on the basis of reason "do not" and proportionality letters and issue warrants, signifies the sanctity of contributions on crime and sins in the holy verse is obvious.[3] Bafghi (1388), emphasizes this point by studying the jurisprudential rule in contributions on crime, that the rule of denying contributions to the crime is famous and conventional jurisprudential rule among jurists and there is in most fields of law, transactions, worship and beliefs. Even in new contracts that, exists general evidence and terms and conditions, are resorted denying contributions rule to the crime. He states three questions, while discussing the rule jurisprudential and its usages discussed in religious books and also is examined the legal effect of the contributions crime. Then states this rule not only in the realm of the individual, but also in the realm of solving people's social and livelihoods problems has extensive benefits and make strengthen the foundations of social relations of human societies and the causes reliability and continuity of jurisprudence cylindrical and solves people's legal issues and is effective and important in the regulation and credit of some legal articles. [4]Shoaib, (1393), reminds explanation and investigation of contributions in crime the debate so far has been from the past. Deputy rule, a rule that would wipe out the factors of corruption in society and jurisprudents resorted to it in various branches of law; he continued to scrutinize in detail the documents and data of this rule; and then has investigated disagreements on the validity of the truth of intent in contribution in crime and at the end the theory of Mohaghegh Ardabili by gathering separation theory between the arrangements of near and far and it has chosen. [5] Mousavi Boroujerdi, (1382), believes that partnership in crime in Islamic jurisprudence and IPC is equal to sin. Has studied the three elements to fulfill of the crime, the legal element, the physical element and psychological element then, explained in detail the realization conditions of partnership in crime and discussing penalty of partnership in crime according to Article 8 of the Penal Code and Article 1 The Islamic Penal Code by the verses and hadiths, pointed out the reason and consensus regarding the unlawfulness of the crime and sins. [6] Raie jan Asli (1381), in the form of a document entitled "The mystery of Penalty of accomplice in the Islamic Penal Code" imposed criticisms against punishments examined for the deputy of crime it reminds flaws.[7] Rahmdel (1389) reviews tips for partnership in crime and states that, the people involved in the crime maybe is one of these three shapes stewardship, participation or complicity.

Also, were investigated by stating some differences and controversial issues that related to accomplice in the crime. According to issues such as unity of intent between the foreman and deputy, The relationship between the deputy and the steward, Effects of the deputy superintendent on assistant after crime, Deputy penalty and the relationship between stimulation and Deputy were discussed.[8] As we know, after the Islamic Revolution The Iranian law inspired by Islamic jurisprudence have been many changes, and the Islamic Penal (1361)Code was replacing the Penal Code in the years before the revolution And reform of the Penal Code has been revised several times If you look at the past trend to legislate on criminal matters after the Islamic Revolution reflects the issue that the criminal law has undergone an evolution. Over time, in practice the advantages and disadvantages of laws appeared and legislators to promote the advantages and solve disadvantages. Based on this the new law is more comprehensive than the previous rules. By comparing the Penal Code in 1370 compared with the laws of hudud and qisas and former diya and the fifth book of the law that was 
passed in 1375 with the sanctions law enacted in 1362 and even the Penal Code 1370 the evolution of that is clear. Can be seen the legislator by passing the new legislation seeks to eliminate the flaws and shortcomings of the previous law. It can be seen that the provisions was predicted in the Penal Code in 1370, were also considered by the legislators at the 1375 law. The Penal Code start by Article 1 and continued till Article 729.[9] And both the Penal Code in 1370 and 1375, was set as a law. However, there are contradictions and ambiguities in the legislation, which has always was attracted the attention of critics, lawyers and experts. Reload IPC in the year (1392) allowed the legislator. While revising the laws reduce flaws and by strengthening other laws provide while perfection of law and was regarded as sturdy anchor for legislators and law enforcement officials. As noted in the previous law in some cases flaws and shortcomings were defects. One of these shortcomings that was reviewed by experts is the rules for its complicity in the crime and punishment. In the revised Islamic Penal Code (1392) legislator has tried to eliminate the weak points to strengthen their relevant laws This study is formed with aims to "review and adapt its jurisprudence abetting the Iranian Law with a focus on new penal code adopted in 1392". So, by using the descriptive - analytic method try to lighten the subject. Therefore, by stating the jurisprudence issues, the deputy in charge of the legal jurisprudence representation of that, by recalling the old rules and Criticisms noted mention the need for these changes. In the final presets results and ends by offering suggestions for its content.

\section{CONTRIBUTIONS ON OF SIN FROM JURISPRUDENCE AND LEGAL PERSPECTIVE}

Contributions means help out and help.[10] This is a verb and words of the personal act or omission arrangements to provide for someone else but culpable is independent and free in his sins committed.[11]

Asam means the sense of sin, haram and what are doing for human beings, is not lawful or indicate the things that keeps people from reward. Sin "Asam" is meant to punish but it seems to mean 'harm'. Similarly, it is said Asam (sin) is anything in which losses. It should be said in the meaning of Asam: It is something that God has forbidden it, whether minor or substantial sins and leave anything that is necessary therefore Asam means absolute sin.[12] Asam means opposing God's command, whether it is the action, or omission.

In the Qur'an, the word Asam and their families (Sm, Asam, Asym, Tasym) on the whole, been used 48 times its original meaning is the illegal operation.[13]Asam come from the same roots in the Quran as a punishment that seems a virtual application. Some said Asam means, practical sin against heart sins, such as envy and Tabarsi the interpretation of the verse

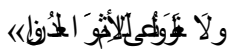

)

Adwan is known as observer of the actions and the Asam is described as omission of the actions. It should be noted that regardless of the fact that "Asam" includes both action and inaction, both to be. But in the debate contribution on Asam only refers to positive action. Because deputy and donations have not foreign meaning in the negative action. . In the Holy Quran words like Muharram, disobedience, rebellion, fine, Zanb and rebellion to the meaning or used slightly different. Some believe Asam refers to the illegal practice that is done on purpose. For example, the verses (105 and 106) of Surah Al-Ma'idah those traits as legal evidence in the inheritance will seek thank and mentioned and said that if not certified to justice, have contribute in sin (Asam), also in verse 20 of Surah Nisa vilify the woman with the intention of not paying his rights and take back what is given to him, "the obvious sin" (Asam expression) is read.[14] Thus, considering the above, can be called "contribution in the Asam 'or' cooperative Adwan and Asam" in Islamic criminal law with the socalled "abetting" criminal law case is in accordance.[15]

Criminal Law enacted in abetting, encouraging or threatening or bribing the crime and provide consumers and providing or facilitating its occurrence in any way, especially through intrigue, deception; For these accomplice is someone who "personally the execution of the alleged offense is to steward dealt with his behavior deliberately to commit the crime it has raised facilitate or steward. "Merle Parade" and "Vito",[16] two prominent French lawyers say: "Accomplice knew that no 
individual can be personally constituent elements of a crime that it is the steward of the day. With their materialist actions, such as providing equipment and irritated, help perpetrator.[17] On this basis we can say that there may be two or more persons without performing operations (material element) participate crime or sin. With its deliberate action or actions in other areas of crime or sin particular role and steward responsible or accomplices or indirectly guilty of committing acts of self-help and assist, to operate in the Islamic criminal law " help on Asam "is said. So contribution in the same Asam abetting crime (including the obligatory leave or commit unlawful) is like selling wine grapes to plant Sazyf rent the house to someone who does illegal work; thirty who committed the murder weapon sales to be and mediating between Rashi (briber) and Mrtshy (bribe) the so-called "Reich" is called (Reich is an active mediator in the realization of victimization of fawn and bribery). It should be noted that today the theory of complicity in acts (including acts or omissions) others, will form an integral part of modern ethical thought, why in modern criminal law only to persons who committed the crime alone and for his are not considering, at present, more than the past has focused on groups that are now in interaction creates a shared responsibility are guilt. This is especially in cases where individuals cooperate fully and unquestionably one another in terms such as governments, companies and organizations a criminal offense to be true.[18]

\section{CRIME}

Crime in the sense of victimization, is sin. Another sense, is cut off the connected actions that is necessary because the mass of the discontinued operation; therefore, guilty sinners say, because good deeds are cut off.[19]

\section{ASSISTANCE}

Assistance or help from a root word meaning help, arrest and support. Assistance word from Bob Mafal and certain definitions, the name of its agent, which means friend, ally and help.[20] ; For example, they say donations Ali Still that helped him. Given that someone who will help in their work, so the meaning of the Asam help, assisting in sin, assisting in sin they are issued by the steward. Assistance with preparation of all or some of the basics of creating a forbidden act is a sinner do. In this regard, the late NARAGHI says the current Assistance of the agent or steward was granted and individual arrangements have provided the action.[21] From a legal perspective, abetting the perpetrator or accomplice to cooperate with law without interfering in the operations of certain forms of crime, prior or contemporaneous occurrence. Under the terms of the nature distinguishes accomplice of a criminal act; this case, if two or more people have direct involvement in the realization of a crime; the nature of the crime if the act have any impact on the realization of the nature of crime.

In this case, these persons are complicit, but if realized abetting a person's deputy, is not involved in the realization of the crime, but only provides work arrangements offenders.[22]

\section{ABETTING (PARTNERSHIP IN CRIME) IN THE IPC}

it was an offense, the perpetrator behind the work, supervision, both intellectual and cooperation, and seek the cooperation of a target, and the fact that such a person be subordinate to the offender assists, but the operation Producer or material element of the crime, not direct intervention, say vice president and Partnership in crime to such an action. Assistance legislator does not define us, but has expressed its various manifestations and forms. Iran's deputy legislative objective or subjective criteria adopted and the type and quality focused operation (not a subjective criterion). Assistance History of Iranian law passed in Articles 28 to 30 of the Penal Code Act of 1304 that are material changes obtained in 1352, Including instances Department of Development has stressed the need for unity of intent and the mitigation of the covenant that court And the provisions in Articles 21 to 23 of the Islamic Penal Law was repeated in 1361, but the legislator (in chastising offenses) to the top of Article 28, adding and abetting the crimes were sentenced to be limited. The last will of the legislator in Articles 43 to 45 and Article 726 of the Penal Code provisions and conditions of the Assistance's words.

B) elements and elements of Partnership in crime 1. The law now permits prosecution as an accomplice of a person is subject to criminal action carried out by the foreman of Ie if criminal action 
is not yet Assistance consequently the will be ruled out that lawyers from the Assistance metaphor or a criminal conviction is not independent but subordinate and subject to the original criminal act. If this metaphor absolute conviction to a penalty equal to know the result will be deputy steward and to that of their unity and purpose; but relative to know if it will be punished, Vice less than steward because he had a lesser role in the realization of a crime that our legislator has adopted the same. Assistance lawyers to consider some independent mass (not Aryhay) as well as in some legal and some independent deputies with a certain penalty for the offense is considered. It is also necessary to note that the deputy is subject to punishment sentencing on the original convictions. But only on the legality of the main verb is enough. For punishment for a perpetrator, time or that he removed the legal sense (article 44 of the Islamic Penal Law).[23]

\section{LEGAL EFFECTS OF CONTRIBUTION IN CRIME (ASAM)}

Criminal law on the crime of accomplice in Iran on this issue there are two separate grounds: a system that is independent Assistance Jeremy knows, these systems perpendicular to the thought that when many people commit crime to the number of participants, independent crime there is, therefore, identify the main perpetrators of the deputies is not the responsibility of every individual must be examined individually.

Crime metaphor system: System metaphor of guilt or complicity to the crime Astarh $\neg$ Ay loan or the like be remembered, is the Vice-Chancellor, an independent criminal but something is subordinate; therefore its realization requires Main is a criminal act to his deputy legal element of the verb to be borrowed. It should be noted that the metaphor of crime is twofold:

1. Absolute metaphor of the crime, namely the principle of equality of penalties for the principal offender and accomplice, because it also has to be stated that the deputies and the principal offenders, the Union and the unity of purpose are of the punishment.

2. Metaphor relative culpability in the system according to the deputy principal offender is punished, but with much lower rates generally decreased to a degree, because the accomplice is less than the principal offender. According to top Article 43 of the Penal Code, it can be concluded that the legislator primarily on the relative culpability has used the metaphor of the system.

\section{THE CONSEQUENCES OF THE CRIMINAL OFFENSE IN CRIMINAL LAW IN IRAN}

Accepted function of metaphor manner relative to the crime of abetting it, the consequences are as follows: A) dependence retribution or accomplice to begin to realize the fulfillment of the original crime and its preparation steward.

B) Amnesty, the amnesty would decline if the criminal character of the action, in this case the mass is not it true that, as Deputy.[24]

C) the position of vice acquitted of crimes punishable offense; if exculpatory causes of crime, and as such act would solidify the legal element of a crime is not regarded primarily foreman, deputy head of the crime and punishment have not been.

D) the position of vice crime in cases where the perpetrator of the offense subject to criminal liability shall be factors in those cases where criminal behavior is attributable to the steward due to lack of capacity because of dementia, or forced or compulsory, criminal liability offense, decays, partners and accomplice are still available prosecuted and punished.

E) assuming the prosecution and punishment of acceptance over time, a plurality believe that if the operation lapse and can not be prosecuted and punished, as a result, abetting the crime lapse and they will lapse. 
The causal relationship between the act and the main mass deputy some lawyers believe that the sins of the main principal deputy and the result of a criminal act, it should be exists customary and reasonable relationship.

And if this relationship was made, describing his criminal department lost and therefore not punishable, unless the legislature to materials, regardless of the punishment of the offender to commit or refrain from committing the original crime.

Investigation of law diagnosis in this relationship reads: said the relationship should be such that if action was not a deputy, was not the main offense or at least in a way that is, not have happened.

Deputy unintentional crimes: Iranian criminal law, complicity in crimes unintentional lawyers have been controversial, and some have flatly denied its realization. Others, without any conditions, inadvertent complicity in crimes have accepted and others have deemed impossible.

According to multiple views of the Supreme Court, unintentional complicity in the crimes of this magnitude is true that with no skills or knowledge to do it, unlike the character in the system, may lead to an accident dangerous, Adjutancy with that person.

Deputy penalty: As the debate over the metaphor of the crime, the punishment Deputy honored principles, different opinions have been expressed. The first theory (system independent deputy crime knows) the main perpetrators should be punished deputies and placed in a row, according to the theories, while the second (metaphor conviction) that underpins Iran's legislative intervention in determining the punishment of the offense, have taken the contribution of each individual and the role that the mass implementation. Article 43 of the Penal Code in this regard says deputy crime on individuals and according to his situation and means and frequency and degree of the offense and the degree of punishment and discipline of preaching and threatened, punished. According to this article, the punishment for abetment of any crimes punishable by death and whether discretionary or discretionary punishment in principle. Therefore the court with regard to all aspects determines, discipline and degrees of preaching and the threat of punishment, such as one or more discretionary punishment imprisonment, fines and flogging.[25]

\section{EXAMPLES OF ABETTING}

In our law department forms and manifestations, Expressed as almost unique in the Islamic Penal Law Article 43. That is all positive action and not allegorical aspect is almost unique. In order to be considered the personal assistant of a crime, should his behavior in one of the cases mentioned in the law were committed (and they are not applicable) these are included:

1. Stimulation, It is meant to stimulate another, this means that thought in mind steward primarily induce crime, or that the criminal thought in his mind empower and build confidence and makes him determined on the offense in the confronting of crime. Some authors, persuasion, inducement, enticement and intimidation of independent and have discussed Apart from stimulating, but it seems that all these are in fact ways to stimulate and induce a person to commit a crime, because the deputy, or the steward promises and gifts and ... want to do that to a crime (bribery) or by pressing certain words and speech and in his desire to create or aggravate the crime (encourage), or by fear of danger or risks (relative to property, life, family, etc.) leads him to commit a crime (threats), so are irritated and moved to the steward in order to carry out the crime. It is also essential that in stimulation of the person in question is not necessary that a certain person but if you were in a steamy, among them one or all of them were committed the offense in question. Mobile Assistant is punishable as stimulating as long as it is effective. The customary lack of stimulation and crime causal relationship exists, otherwise if your main perpetrator of the crime have enough incentive. So that if it was not stimulate the deputy was still perpetrator can not be realized. We have some important legislative irritation due to its high risk as an independent crime and is considered as a particular penalty, however, it also happened to be the original crime or even begin to realize it is not a crime. The purpose of the criminalization of independent lawmakers such cases, prevent major accidents and irrecoverable and 
put out the fire of sedition in the bud. (Such as crimes against national security, such as inciting people to war and destruction, corruption, and encouraging people to stimulate the militants to flee or surrender). Intrigue, deceit this three are synonymous with each other and with the kind of secrecy and deception go together. In order to deceive the victim or a third person has committed a crime of the principal offender in question could be easily. Like a mock accident or claim against the driver of the car, so he walks and a criminal mastermind (steward) to steal the car or to talk and distraction seller to showcase the jewelry, the foreman at the right moment to act the stolen jewels. Providing means for committing the offense. In paragraph 2 of Article $43 \mathrm{AH}$. We. Provided, that is, build or provide any means (movable or immovable) for the offense, is Vice-Chancellor of the best examples. It is clear that for realization of crime Assistance should be established unity of intention that is made by the Deputy in bad faith and intended to commit the crime's steward. And he is also a practical means to commit criminal acts. So it proved in court to punish him knowingly and deliberately deputy is necessary to see through crime. Is that the deputy, a plan for how to steward prepared and presented to the commission of a crime and the provision of information about crime and how to use equipment, time and place of the use and the steward, course this Guidance should wisely, is concerned deliberate and effective crime. Facilitate the offense in paragraph 3 of article 43 as the last instance of the Deputy listed. This means that the shapes and forms of crime by the steward at the same time, make it easy crime by the principal offender.

She also acted in a way that facilitates letters of the crime. As if someone lurking outside and watch the victim to the thief's home, police presence or risk of timely notify the landlord. And this has led to less security alarmed and attempted to steal confidently. Here, however, there is also facilitating crime and establish knowingly and deliberately, to determine the condition result in punishment.

Specific forms of assistance in law (Hodoud and nemesis)

1. Contribution in drinking alcohol in accordance with Article 175 of Islamic Penal Law Sentenced to 74 lashes.

2.punishable complicity in theft, too, that the Tsrh 2 Article 21 of the IPC in prison, sentenced to 1 to 3 years.

3.complicity in the murder, which is punishable by terms of Article 207 of the Islamic Penal Law From 3 to 15 years in prison and in the absence of the complainant or his forgiveness, according to Article 208 and 612 is reduced Q.m.a.bh 1 to 5 years.

4.complicity in deliberate amputation or injury that according to Clause 1 of Article 269 Q.m.a.mrtkb to imprisonment of 3 months to 1 year and 2 months to 1 year in accordance with Note 2 to be sentenced.

5.assisting in abortions, in accordance with Rule 623 BC. We. Sentenced to 6 months to 1 year in prison.

6.vice of corruption and prostitution that occurs in terms of Article 639 to 1 to 10 years in prison;

7. Vice-Chancellor (Applause) objects in the transaction referred to in Article 640 AH. D. A. Sentenced to imprisonment, fines or flogging screw.

8. Assistance in setting up and operating casinos and a center of corruption under Article 710 [IPC] perpetrator's punishment, and the punishment of imprisonment or a fine steward listed in Article 708 from 3 to 12 million Rials.[26]

\section{PLAN SOME BUGS ON THE ABETTING}

Article 726 of the Penal deputy in prison for crimes says, "Everyone crimes according assist as the case may be sentenced to the minimum penalty prescribed by law for the same offense."

First, with regard to the role of vice president in charge of the realization enclosed in providing means for committing crimes or threats, lure, entice, provoke or facilitate the commission of a crime and ... . And the company does not in any way appropriate to punish crime enforcement operations deputy to be determined in a way that in any case the punishment is less severe steward, And to determine punishment based on the ruling by the court even exist, but according to Article 726 if a court ruling determines the minimum punishment for the perpetrator. An overview shows that in many cases in 
determining sentences in Iranian courts to impose a minimum punishment is enough and even in many cases by applying the mitigation of the punishment less severe punishment is determined at least).[27]

As a result, a crime punishable by a foreman and assistant foreman equally be determined and given that now proves itself in operation, the degree of courage and risk that creates for individuals and society in relation to accomplice is at the upper limit. In any case the punishment for someone steward and deputy legal logic and principles of justice and the penal goals the appropriate approach is not consistent with criminals and the principle of proportionality between crime and punishment has not been met, lawmakers must determine a way to limit penalties to evaluate permissible under any circumstances for the steward and deputy does not exist, there is no doubt basically, people who grade their daring and dangerous than people. Indeed, attempts to commit the crime itself shall act as deputy to attend the mass of the people do not have enough preparation and one of the factors that can interfere deputy and now these people in operation to prevent and policy measures on the part of the legislator in determining the punishment is more severe for the steward which can be used as a powerful deterrent to prevent crime from the company's executive vice president of operations and the deputy thoughtful stewardship of the severity of punishment, it seems not a crime to participate in the operation, when lawmakers criminal penalties to appoint a way that even the possibility of punishment by court order is to steward and deputy this person is guilty of deputy encouraged to participate in operations when they see accomplice his act is punishable by providing and facilitating crime and the punishment is likely that the perpetrator obviously prefers its own motion that the crime attempted personally and get greater benefits. Therefore, it is appropriate to punish lawmakers a way to appoint deputy which allows you to determine the punishment for the person and deputy steward does not exist in any circumstances. (B) All persons who committed offenses while to a degree not harmful for the society and its people and ruling the court noted several factors that are involved in crime and with respect to the causes and motives of the crime and how often a person has committed a criminal offense and to consider other ways to determine the appropriate penalty and thus what lawmaker in all countries and Iran to the perpetrator does not set a fixed penalty and in sentencing and may set a minimum and maximum The maximum penalty is a crime punishable by at least several times for example, in substance, 651, 653 in the case of theft punishable by imprisonment from 5 to 20 years legislator has set for burglars according to the court ruling on the causes and motives of times the mass of Muharram committed a crime and attention to other directions that are involved in crime. It seems attempted to determine the appropriate penalties on offenders. The different causes and motives and often commit a crime and should be taken into account in sentencing in charge the deputy and in sentencing these offenders also a legislator determine the minimum and maximum, the court considering all the conditions and circumstances of the crime that affect a person's deputy and given the mood steward and deputy and other effective ways to determine the appropriate punishment for crime and determining a fixed penalty was not accepted in today's world and in accordance with the legal logic of rights and principles of justice and is not the principle of proportionality between crime and punishment. Fortunately, the same thing legislator in Article 43 of the Penal Code considered in this article says "The following persons regarding the conditions deputy in crime and delinquent facilities and the frequency and degree of the offense and the degree of punishment and discipline of preaching and threatened, punished."

It is not clear why in Article 726 hip everything is considered in Article 43 forgotten and ignored and attempted to set a fixed penalty for the offense has deputies. Third-Article 726 of the Penal Code to punish accomplice in the crimes and sentenced not ruling accomplice in the case of retaliation and Diya and legislators in this category of offenses the punishment has determined separately for accomplice but there are cases The Penal Code is silent about them, including: Lawmakers approved the Penal Code of 1361 did not determine the punishment for deputy in murder. The bug has been fixed in the IPC 1370 and in the second part of Article 207 of the Penal deputy has nominated from 3 years to 10 years in prison on a murder but in quasi-intentional murder is punishable by a steward to pay the blood money to punish accomplice is still silent and according to the specific type can not be said that it will be clear below quasi-intentional murder is not a crime legislator in Article 206 of the Penal Code knows for premeditated murder in three types: 
"A) When the murderer intended to kill the person by doing something a certain person or certain people is a collective whether or not it causes death, but the results in death;

B) cases where the murderer intentionally do something which is inherently lethal, even not intend to kill someone;

C) When the murderer intended to kill do not have and what they do are typically not fatal but due to illness or old age or disability or to the child, and so they typically fatal, and the killer is aware of that ".

According to the terms mentioned in this article if you have to kill another man without being punched or kicked or instruments that are typically not fatal, the assault was not attributed to the party so that it operates both in terms of age, disability and disease are typically not fatal and it happens to be the practice, killing him, the murderer of the action is deliberately and intended outcome is extreme slight result, but it happens, the result is the same as murder. This three ways takes place according to the terms and conditions referred to in Article 206 can not be premeditated murder. and such quasiintentional murder and the murderer must pay the blood money to the heirs to the blood.

Regardless of whether in these slayings to punish is not enough to punish Diyeh with the comparison of wrongful killings in which the blood money deal is punished killer by the punishment fit the crime is not logical. In the case of abetment of the crime, punishment has set the current legislation for example, if in such murders a man with supplying equipment to the foreman delivered the person committing the crime beat, which happens to be helped murder.

Deputy person can not be prosecuted because the law does not specify punishment for abetment of such killings and the silence of the legislature can not carry on his practice was not a crime because it is not acceptable that if it were not killed beat deputy crime under Article 726 to be prosecuted for aiding and abetting intentional assault but if it happens multiplying the mass killing action dismissed vice Therefore, it is necessary legislator as deputy penalty in murder legislative vacuum in the Penal Code to address this shortcoming also eliminate the appointed by year70 tried to solve it. In addition to shapes that were wide-Rabia has other ways to describe below is based on Article 726 of this Article has appointed, deputy in crime punishable by prison terms of the minimum punishment is prescribed by law for the same offense talk while suspended in the Penal Code punishes offenses specified in Articles 645- 637-602-598-575 that the minimum sentencing legislation without mentioning the word (to) is attempted to determine the maximum punishment. In fact, the minimum penalty is a punishment to the primary unit, however the minimum penalty under article 726 of the Penal accomplice. So, slight and insignificant that the deterrent effect and the discipline of zero and virtually useless and non-proportional and in cases where the judge is entitled to his steward accomplice to recognize discounts will not be possible to apply the discount. For example, Article 645 of the non-registration of marriage and divorce, see "The honor of the family in order to maintain the registration of marriage, divorce, and reference is mandatory, if a man without registration in an official attempt to marriage, divorce and refer to the punishment of imprisonment sentenced to a year ». The legislator expressed to one year in prison, indeed, from one day to one year in prison is to order, so if someone, is assisted somehow guilty of the crime, court under Article 726 can not be accomplice in this case to appoint more than one day in prison and Article 637 of the criminal affair, says: "If bond between man and woman who are not married, commit adultery or fornication acts incompatible with other than such as are Taqbil or Mozaje'eh. Ninety-nine will be sentenced to whip up a shot, and if you act with force and coercion by punishment is only reluctantly.

The minimum punishment for the offense mentioned in this article lashes 1 and if someone in the victim's deputy governor lashes court can appoint more than one and even legislators in article 575 of the criminal penalties are not set minimum and maximum and no minimum punishment under this article is in fact a crime has mentioned in this matter. If the judicial or other competent authorities ordered the arrest or detention or criminal prosecution against the law or someone's culpability issue 
to permanent dismissal from the judiciary and banned from public office will be condemned for five years. "Given that the minimum punishment has not determined for the offense legislator, so if you are the person in the crime department, court ruling could determine his punishment because the punishment accomplice in crimes according to article 726 of this law the minimum punishment is prescribed by law while the minimum penalty has not been set for the offense. In line with the amendments in the Penal Code (1392) in the third quarter provides: According to Article 126. The following persons are accessary:

A. Everyone persuade others, threaten, bribe, or incitement to commit a crime or a conspiracy or a deceit or abuse of power, would be a crime.

(B) Make or provide every means of committing a crime or commits a criminal offense to offer.

(C) Facilitate anyone crime.

Note: to realize abetting, unity of purpose and priority or time coupling between behavior and crime deputy condition if the original solitaires crime, serious crime than what is intended by the abettor is guilty of deputy Vice-chancellor of the lesser offense shall be sentenced to punishment.

Article 127 If in the Sharia or law, is not permitted to Vice determined, the punishment would be as follows:

(A) Legal in those punishable by deprivation of life or is life imprisonment, imprisonment of two or three.

(B) The extent theft and intentional clipping member of imprisonment of five or six.

(C) They are legal in those punishable by flogging extent thirty-one to seventy-four lashes discretionary sixth grade.

(D) The crime would be punished by one to two degrees lower than the committed punishment for the crime.

Note 1: In the case of paragraph (d) of this article shall authorize the Deputy of legal punishment for the crime committed, except in cases of confiscation of property, permanent expulsion and conviction of a crime that carries a fine vice president is respectively of four, six and seven.

Note 2: If for any reason a member is not executed retaliation or punishment on the basis of punishment agent deputy of the crime, applies in accordance with paragraph (d) of this Article.

Article 128: Everyone has documented the use of a minor as a crime shall be sentenced to the maximum punishment for the same crime. Deputy addition, anyone who is a minor in criminal behavior complicity in the crime was sentenced to the maximum penalty.

Article 129: When you commit a criminal act committed in the direction of the personal aspects such as the madness, is not traceable or prosecution or execution of sentence to the direction of these ways, we'd be no impact on the prosecution and punishment of vice crime. According to the law, has established in accordance with Article 728, the General Penal Code 07/11/1304, 03/07/1352 General Penal Code, 05/18/1362 Islamic Penal Code, the Penal Code, adopted on 08/05/1370, materials (625), (626), (627), (628), (629), (726), (727) and (728) of the fifth book of the Penal Code "in prison and deterrent punishments" Act of 03/02/1375, the security measures adopted on 02.12.1339, and the definition of effective convictions in criminal law adopted on 07.26.1366 and subsequent amendments and extensions unless the prescriptions in other previous laws and other laws contrary to the date of entry is repealed into force of this Act. 


\section{RESEARCH FINDINGS}

The difference abetting provisions in the new Penal Code and the former states that: Prior to the adoption of the fifth book in Persian date Khordad 1375 Penal Code Penal accomplice to the judge under Article 43 of the former law court. That due to specific conditions and opportunities and degree of the offense, it determined the amount, in the cases where imposed the law or other rules, legal transition type and amount of the penalty. The court verdict were carried out within the provisions of Article 726 of Law sanctions was found then imposed the sentence on crimes according deputy, the minimum penalty prescribed by law for the same offense. Finally, pursuant to Article 726 of the Penal Code Act 1392 was repealed sanctions and legislative provisions related to assistance in a variety of offenses and penalties has summarized in Articles 126 to 129 of the new law. Also, given that in different materials suspended Deputy Vice Chancellor in premeditated murder punishable as provided in Article 612 Therefore, given that Article 127 is mentioned in rulers.

Another punishment that the law is not specified, but Article 612 of the Penal appointed deputy vicechancellor discussed the other hand, the new Penal Code also sanctions has removed only Article 726. A reference to Article 612 is not; however, due to the clear provisions of article 127 of the Penal Code Act 1392 if other virtual or Sharia law is not specified for deputy. As set forth in the following paragraphs of this Article punishment deputy determined, so according to the Sentencing deputy in murder-in-law that Article 612 of the Penal Code adopted in 1375 should be based on the provisions of punishment deputy determined between these two materials is no conflict, another point about the punishment of a crime under Article 576 of the Penal Code sanctions the separation of government services is 1 to 5 years, temporary suspension Penal accomplice material is subject to the discretion of the judge dealing is involved with common research department.

Accomplice in the crimes for which the legislator to specific punishment for that offense did not foresee is if the sovereignty of the Islamic Penal Code 1392, the former by virtue of Article 726 of the Penal Code can be used to punish vice, but if the rule of the Islamic Penal Code, adopted in 1392 after charges against Deputy is based will be on the following amendment to paragraph (d) and Article 127 of this law. According to paragraph of Article 127 of the Penal Code adopted in 1392 when the eight individual crimes according assist. The court could determine the punishment according to Article 127 of the Penal Code, adopted in 1392 but in religious or other authorized law is set to deputy, he punished as paragraphs a, b, c and d determine the matter, since the Islamic penalty is divided into eight degrees and 8 degrees punished imprisonment for up to three months or a fine of up to ten million Rials, or whip up ten hit. That the investigating authority could determine punishment for the perpetrator can be at least a minimum of one day and a penny and lashes. Therefore, when the perpetrator, to allow at least eight penalties specified in the crime and punishment and that's assuming asked to accomplice to two low degree of punishment that has not been predicted lower degree of grade 8 . It seems that according to the principle of legality of crimes and punishments on vice crimes referred to in paragraph 8 of Article 127, if the grade is, the legislator has not determined a punishment for them and therefore subject to punishment shall be determined as set forth is ruled out in inquiries and what is not relevant.

\section{THE RESULT OF RESEARCH}

In this study, we look at jurisprudence and legal arguments were examined and abetting was obtained as the result of research. It became clear that one of the most controversial issues in the Penal Code, the Penal accomplice is a problem. Article 43 of the Penal Code had been predicted in 1370 that the three persons mentioned in paragraphs Article due to his situation and means and frequency and degree of the offense and discipline, are preaching and threats and degrees of punishment, "punishment". Considering the history of this provision in the Penal Law (1361) it became clear that abetting, previously only imagined offenses punishment. This is why the legislator also for the Vice such crimes, "punishment" was considered. With the approval of Article 43 of the Penal Code in 1370 without regard to its conflict of law and punishment as opposed to the principle of legality of crimes and punishments, the criminal punishment can be extended to all crimes but the Penal accomplice, did not change the result. However, in Clause 2 of Article 43 was predicted that if a certain punishment for vice crime in canon law the same punishment will be applied. 
But the few examples in the law and apply the word "religion" in a general sense and vague in this note, he did not open not only the knot of the problem but it also adds complexity. However, in 1375, this time in the context of Article 726 of the Penal Code (sanctions and preventive punishments) legislator After overcoming this difficulty outcome. However, there was no objection to this matter fully accountable, because only example of Clause 2 of Article 43 was, however, the question that arose with the adoption of Article 726 of the Penal Code has been repealed Article 43 but it was clear that Article 726 as determining a particular sentence can not be abrogating Article 43, which defines general rules abetting. However, Article 726 of the applicable statutory provisions (2) Article 43, despite the legislator in accordance with the provisions of Chapter III of the Penal Code 126-127-128129, explained has done Deputy crime in the Penal Code Act of 1392 and the abrogation of Article 726, put the criticisms of this article we review the revised law. Thus, a conclusion can be added to the scope of the judge. Judges can be said with regard to legal rules and the Penal Code, the Articles of special attention. The important thing is that in the IPC on the basis of the legal rules notice on contribution in Asam (sin) and by taking it to define accomplice is considered sanctions, but the laws of other countries, according to some criminological theories and legal principles to define accomplice in crime and cases of criminalization of the resolution of the Iranian Constitution, on the basis of the researcher suggests:

1. Defining accomplice with the jurisprudence and legal scrutiny based on the consideration that cut any review on the subject;

2. To define and punish vice president in charge in addition to the legal rules can be considered legal opinions in other countries will also be of interest to legislators, it is clear that can be formed conducting comparative studies.

3-accomplice in bribery more of the issues and concepts in the Act, because according to the country's need for economic development is essential to block the way of any assistance in carrying out these crimes.

4. In order to prevent crime and make the most of security, rules and legal principles can be considered from an educational perspective to look at groups of people abetting the sin.

5-crime laws can clear rise in crime issues and developing and expanding it can also reduce the look of sin and the Role of the community extends to play an important.

\section{REFERENCES}

Fletcher, George sought, (1384), the basic concepts of criminal law, Translator: Mehdi Seyed-born Sani, Mashhad, Razavi University of Islamic Sciences, First Edition, pp. 318-331

laws and Islamic penal responsibilities that the god of this world for sinners determine: whether they are related to sins that have specific punishment or other sins, including the punishment of crime, physical or financial , called Islamic criminal law, in the past, this type of regulation "political" saying, Georgian, A., et al., (1381), about, sanctions and retaliation, Tehran, Tehran University Press, first edition, p. 6

Ahadi, Saifullah, Fakh-aly, Muhammad Taqi, (1393), research on the implications of the Quran ( $y$ ) (تعاونوا على الاثم و العدوان ) help prohibition on Asam and Adwan, Journal teachings of civil jurisprudence, autumn and winter, Issue 10, Page 3-30.

Bafghi, M., (1388), rule of law assistance on Asam, Quran and Hadith Sciences, rhetorical expression, winter and spring, 17 and 18, pp. 175-196

Shoaib, Meysam, (1393), explain and review the funding rule on Asm, Quran and Hadith Sciences, rhetorical expression, spring and summer, numbers 38 and 39, 107-130

Mousavi Boroujerdi, SM, (1382), abetting, Matin Journal 1382 No. 18, S3-16

Rayjian asli, M., (1381), the mystery of the Penal accomplice in the IPC, Justice Law Journal, Fall, Number 40, 33-58 
8.Rahmdel, M., (1389), Notes on abetting, free legal research, summer and winter, No. 8-9-10, pp 161-185

tahmasebi, J., (1380), Conflict Penal Code in 1370 and 1375, rights, Bar Association, Summer, No. 173, pp $27-37$

Amid, H., (1375), Persian Culture, Tehran, Amir Kabir Publishing, Printing 8, Page 200

Khoi Mousavi, A., (Beata), Misbah Al feqahat, Vol. I, p. 179, quoting Mecca Khoi, Khalil al, (1386), principles of jurisprudence and laws, Tehran, the publisher, 2nd edition, $\mathrm{p}$.

Bafghi, former Page 176

Mohaghegh. damad, (1406), p 179

Mohaghegh. damad ,Yazdi, Sayyid M., (1406 AH), the legal rules, Tehran, Press Center of Islamic Sciences, Twelfth Edition, Volume 4, Page 179

Ardebili, MA, (1379), Basic Criminal Law, Tehran, published in, first edition, Vol. I, pp. 69-70

Ardebili, MA, (1381), Basic Criminal Law, Tehran, emission levels, 4th edition, Volume 2, Page 39

Nourbaha, R., (1382), General Criminal Law, Tehran, Dadafrin publishing, printing, 8, p 228

Fletcher, George sought, (1384), the basic concepts of criminal law, Translator: Mehdi Seyed-born

Sani, Mashhad, Razavi University of Islamic Sciences, First Edition, pp. 17-316

Qureshi, S., (1310), Glossary of Terms Quran, Qom, Almaktabeh Almortazavieh, Volume 1, Page 27

Pour Safi, H., (1374), culture, legal terminology, Qom, charter schools elmiyeh Islamiyeh, Volume 3, Page 289

Naraqi, Ahmad bin Muhammad al-Mahdi, (1376), revenues per stated rules of inference Ahkam AlAyyam, Qom

Bafghi, M., (1388), rule of law assistance on Asam, Quran and Hadith Sciences, rhetorical expression, winter and spring, 17 and 18, pp. 175-196

Said, A., (1388), a comparative study on the rights abetting Iran, France and Lebanon, rights, judge, June and July, 57, 48-52

al-Fadhil, M., (1378), Almsulyh Aljzayyh, Beirut, Daralmshrq, p. 228

. Bafghi, M., (1388), rule of law assistance on Asam, Quran and Hadith Sciences, rhetorical expression, winter and spring, 17 and 18, pp. 175-196

Said, A., (1388), a comparative study on the rights abetting Iran, France and Lebanon, rights, judge, June and July, 57, 48-52

Darvish Motevelie, J., (1378), 20 forms in the Penal Code, Law, Law Justice, Spring, No. 26, pp. 141166 